\title{
Effects of organic fertilizers on growth and biochemical characteristics of Fenugreek
}

\author{
${ }^{1}$ S. ALAGHEMAND, ${ }^{1}$ H. AYYUBI, ${ }^{1}$ E. HASANPOUR, ${ }^{1}$ J.A. OLFATI, ${ }^{2 *}$ M. SAADATIAN, ${ }^{1}$ Y. HAMIDOGHLI \\ ${ }^{1}$ S. KAZEMI AND ${ }^{1}$ H. KARIMI
}

Received April 10, 2016; accepted April 10, 2017.

Delo je prispelo 10. aprila 2016, sprejeto 10. aprila 2017.

\begin{abstract}
Fenugreek (Trigonella foenum-graecum L.) is an annual herb used as organic (green) manure and has medicinal applications. Organic fertilizers are used in sustainable agriculture of vegetables. Sources of organic manure and their effects on growth and yield characteristics of plants need to be determined. Effects of vermicompost and vermiwash were determined on qualitative and quantitative factors of chemical content, development and yield of fenugreek (Trigonella foenum-gaecum L.) from May to July 2012 at Agriculture College of University Guilan. A completely randomized block design with 3 replications was used. Treatments included 7 $\mathrm{t} /$ ha of cow manure, vermicompost, vermiwash (obtained from $7 \mathrm{t} / \mathrm{ha}$ vermicompost); $7 \mathrm{t} / \mathrm{ha}$ of leachate vermicompost + vermiwash and a control (no fertilization). Use of organic fertilizers beneficially affected plant height, pod length, pod fresh and dry mass, 1000-seed mass, plant fresh and dry mass, internode length and percents of leaves protein and nitrogen. Use of organic fertilizers may increase yield and yield components of fenugreek and its yield efficiency.
\end{abstract}

Key words: Trigonella foenum-graecum L.; yield components and their chemical composition; organic fertilizer; sustainable agriculture; vermicompost

\section{IZVLEČEK}

\section{UČINKI ORGANSKIH GNOJIL NA RAST IN BIOKEMIJSKE LASTNOSTI SABLJASTEGA TRIPLATA}

Sabljasti triplat (Trigonella foenum-graecum L.) je enoletno zelišče, ki se uporablja kot organsko (zeleno) gnojilo in je uporabno tudi v medicini. Organska gnojila se uporabljajo v trajnostni pridelavi zelenjave. Vire organskih gnojil in njihove učinke na rast in pridelek rastlin je potrebno še preučiti. Učinki komposta deževnikov (vermikomposta) in njihovih izcedkov (vermiwash) na kakovostne in količinske parametre kemijske sestave, razvoja in pridelka sabljastega triplata so bili preučevani od maja do julija 2012 na Agriculture College of University Guilan. Uporabljen je bil popoln naključni bločni poskus s tremi ponovitvami. Obravnavanja so obsegala: $7 \mathrm{t} / \mathrm{ha}$ kravjega gnoja, vermikompost, vermiwash (pridobljen iz 7 t/ha vermikomposta); 7 t/ha izcedka vermikomposta + vermiwash in kontrola (brez gnojenja ). Uporaba organskih gnojil je ugodno vplivala na višino rastlin, dolžino strokov, suho maso, maso 1000 semen, svežo in suho maso rastlin, dolžino internodijev in na odstotek beljakovin in dušika $v$ rastlinah. Uporaba organskih gnojil lahko poveča učinkovitost pridelka in njegovih komponent pri sabljastem triplatu.

Ključne besede: Trigonella foenum-gaecum L.; pridelek in njegova kemijska sestava; organska gnojila; trajnostno kmetijstvo; vermikompost

\section{INTRODUCTION}

Fenugreek (Trigonella foenum-gaecum L.) is an annual herb used as organic (green) manure and has medicinal applications (Kaviarasan et al., 2007; Bukhari et al. 2008; Haouala et al., 2008). Seed of fenugreek contains lysine and L-tryptophan, proteins, mucilaginous fiber and saponins, coumarin, fenugreekine, nicotinic acid, sapogenins, phytic acid, scopoletin and trigonelline (Bukhari et al., 2008). Polyphenol content in vegetables can be affected by environmental factors, cultivation, and conditions at, and after, harvest (Suthar, 2008). Organic fertilizers improve soil $\mathrm{pH}$ and cation exchange capacity (CEC) and increase micro-organism diversity

1 Department of Horticultural Science, Faculty of Agricultural Sciences, University of Guilan, Rasht, Iran

2 Soran University, Faculty of Education, General Sciences Department, Soran, Kurdistan Regional Government, Iraq; Corresponding author: saadatian@hortilover.net 
and activity (Renato et al., 2003). Excessive applications of chemical fertilizers reduce plant performance due to soil acidification, reduced soil biological activities, degradation of soil physical features, and lack of micronutrients (Adediran et al., 2004). Use of compost materials results in improved soil fertility (Kasthuri et al., 2011). The garbage earthworm (Eisenia fetida (Savigny, 1826)) digests organic waste and converts it to materials beneficial for plant growth; the final product of its activity is called vermicompost (Gunadi et al., 2002). Materials produced by earthworms contain several nutritional substances easily available to plants (Suthar, 2008; Taylor et al., 2003). Vermicompost has high porosity, high potential of uptake and storage of mineral elements, which are gradually released. It also has high water holding capacity, and is used in sustainable agriculture of vegetables (Arancon et al., 2004a; Atiyeh et al., 2002). This research was conducted to evaluate effects of sources of organic manure on growth and yield characteristics of fenugreek to identify which is the best for natural antioxidants, total phenol and protein content in seed.

\section{MATERIAL AND METHODS}

For producing vermicompost, $25 \mathrm{~g} / \mathrm{kg}$ or $2.5 \mathrm{~kg} / \mathrm{m}^{2}$ earthworm were added to the cow manure bed and vermicomposted for 2 months (Peyvast et al., 2008). For producing vermiwash, 501 of water was added to 100 $\mathrm{kg}$ vermicompost and after $48 \mathrm{hrs}$ extracts were purified by passage through a textile filter. The experiment was conducted at the University of Guilan Campus, Agriculture Faculty, Rasht, Iran (altitude $7 \mathrm{~m}$ below mean sea level, $37^{\circ} 16^{\prime} \mathrm{N}, 51^{\circ} 3^{\prime} \mathrm{E}$ ), from May to July 2012. Annual average temperature is $15.9^{\circ} \mathrm{C}$. Thermal amplitude is $35.3{ }^{\circ} \mathrm{C}$ in summer and $6.6{ }^{\circ} \mathrm{C}$ in winter.
Average rainfall is about $1359 \mathrm{~mm}$ per year with most occurring during late summer. The loam soil was plowed, disked and clods broken. Raised seedbeds, 0.3 $\mathrm{m}$ wide and $15 \mathrm{~cm}$ high, were prepared. Seed were planted in rows $15 \mathrm{~cm}$ apart at a depth of $0.5-1.0 \mathrm{~cm}$ on 23 April 2012. The bed surface was covered with a $1 \mathrm{~cm}$ of vermicompost or soil. Before spreading fertilizers, 3 mixed samples of soil were selected from 0 to $30 \mathrm{~cm}$ depth with 3 replications. Samples were dried in the air, and contents determined (Table 1). Furrow irrigation was used at 2 day intervals.

Table 1: Chemical and physical characteristics of soil (Greenhouse building at University of Guilan, 2012)

\begin{tabular}{|c|c|c|c|c|c|c|c|c|c|}
\hline & & & & Available & Available & & & \\
$\mathrm{K}$ \\
Soil
\end{tabular}

A completely randomized block design with 3 replications was used. Plots were $4 \mathrm{~m}^{2}$. Treatments included 7 t/ha of vermicompost; vermiwash (obtained from 7 t/ha vermicompost); vermicompost leachate + vermiwash from $7 \mathrm{t} /$ ha vermicompost and a no fertilizer control (levels of nutrition in the soil sufficient for the crop which the recommended nutrition levels may not be correct and we are testing the additional fertilizer to determine if it provides a benefit). Vermicompost and leachate vermicompost were spread over beds and vermiwash applied 3 times at 7 day intervals. At flowering plant height, plant fresh and dry mass, pod fresh and dry mass, number of nodes, number of lateral branches, internode length, number of pods, pod length, number of seed per pod, total phenol, percent of antioxidant activity, fresh yield, dry yield, and contents of nitrogen and protein in leaves were determined. The Bradford protocol (Bradford, 1976) was used to determine protein amount in seed. The DPPH ability for scavenging free radicals was determined based on the method of Du et al. (2009) with minor modifications. Briefly, $50 \mu \mathrm{l}$ of fenugreek extracts were added to 950 $\mu$ l of a $6.25 \times 10^{-5} \mathrm{M}$ solution of DPPH in methanol. A control sample containing the same amount of solvent in place of extract was used for measuring maximum DPPH absorbance. The reaction took place in the dark for $30 \mathrm{~min}$; absorbance at $517 \mathrm{~nm}$ was measured to determine the concentration of remaining DPPH. The 
percent DPPH, which was scavenged (\% DPPHsc), was calculated using:

$\%$ DPPHsc $=$ Acont - Asamp $/$ Acont $\times 100$

where Acont is absorbance of the control, and Asamp is absorbance of the sample. Total phenols were determined spectro-photometricaly using FolinCiocalteau colorimetric method with modifications as described by Singleton et al. (1999). Data were subjected to ANOVA in SAS (ver. 9.1, SAS Institute, Inc., Cary, NC) and means separated using the Tukey test.

\section{RESULTS AND DISSCUSSION}

The organic fertilizers did not affect numbers of pods/plant, number of seed/pod, number of nodes, number of lateral branches, antioxidant capacity, total phenols, and dry yield (Tables 2 - 4). Fertilizer affected plant height, pod length, pod fresh mass, 1000-seed mass, plant fresh mass and internode length; there were no differences between vermicompost types (Tables 2 4). In no fertilizer control the soil nutrient content is sufficient for some, but not all, benefits to the crop. However the lowest value was obtained from the unfertilized control of many traits. Organic fertilizers gave the lowest 1000 seed mass, plant fresh mass, plant dry mass, protein and nitrogen content of seed were obtained from control plants; fertilization decreased pod dry mass (Table 2 - 4). Plants treated with vermicompost were the tallest, as reported by Yadav et al. (2003), Arguello et al. (2006) and Almulla et al. (2012) in other crops. Organic fertilizer enhanced plant height what could be due to the plant hormone auxin (Muscolo et al. 1999). Organic fertilizer can affect soil properties and suppress plant diseases and improve plant health. Pod length was increased by vermicompost treatment and pod length may be related to seed yield via indirect effects of vermicompost on seed yield via pod length. The highest pod fresh mass was due to the vermicompost treatment. The 1000 -seed mass were different between vermicompost and vermivash treatments. Plants treated with vermicompost had the highest total yield/ha (Table 4). It may be that chemical and physical properties of humic acid in vermicompost increase uptake of hormones and nutrients resulting in improved growth and yield (Arancon et al., 2005), increased soil microorganism activity (Arancon et al., 2004b), improved nitrogen accumulation, and increased total yield. Plants treated with vermiwash + vermicompost had the longest internodes. Renato (2003) reported that organic fertilizers in the soil can increase element uptake. Organic manure increases soil aggregation, aeration, water holding capacity, and supply roots with an extended source of nutrients (Rani and Nishana, 2012). Vermiwash increased fresh and dry mass; it may be that organic fertilizers increased water absorption through distribution and development of roots. Mucus deposit of epidermal cells and coelomic fluid produced by worms contain plant hormones and chemical exudates (Rani and Nishana, 2012).
Antioxidant capacity was not affected by organic fertilizer which contrasts to those of Haghighi (2011) using sewage sludge on leafy vegetable growth. High antioxidant capacity was recorded in the vermicompost treatment. Haghighi (2011) indicated that a deficit of nutrient availability and uptake in the control induced antioxidant activity. Pant et al. (2009) claimed that low plant growth and $\mathrm{N}$ concentration caused high level of antioxidant activity in leafy vegetables. Amounts of phenolic compounds in plants grown under organic conditions are higher than those grown under inorganic conditions (Asami et al., 2003; Dixon, 2001) which contrast with our results. Higher total phenolic compounds can cause the decrease in environmental stress to plants (Asami et al., 2003). Higher levels of total phenolic content was found in plants treated with vermicompost compared with those grown with Osmocote (a type of trade fertilizer) and this was attributed to a gradual release of available nutrients in plants from vermicompost (Asami et al., 2003; Pant et al., 2009; Wang and Lin, 2002). Protein and nitrogen contents were affected by fertilizers as also reported by Kasthuri et al. (2011) who found that Municipal Solid Waste Compost affected protein content of fenugreek. The protein and nitrogen contents increased with vermiwash + vermicompost leachate treatment. It may be that soil microorganism activity under high manure (Arancon et al., 2004b) results in nitrogen accumulation in plants due to increases in protein and organic manure affected soil amylase, invertase activity and cellulose and increased microbial biomass (Kasthuri et al., 2011). Vermicompost (Peyvast et al., 2008) and vermiwash (Suthar, 2010) were proposed as organic fertilizers but there is no information on effects of the combined application of vermiwash and vermicompost on vegetables. The main problem that can arise from excessive application of vermicompost is toxicity due to high salt content. With leaching, negative effects related to high salinity decreased and continuous application of this material may be possible. Vermiwash and leachate vermicompost can be used as fertilizers for cultivation of organic fenugreek. Application of organic fertilizers may help alleviate salinity and sodium problems that develop as a result of excessive chemical fertilizers and irrigation (Almulla et al., 2012). Using sustainable and environmentally friendly organic materials can increase 


\section{S. ALAGHEMAND et al.}

fertility without negative effects on human health and the environment. Organic fertilizers effects especially were continued during next year and their beneficially vermicompost, vermiwash and vermicompost leachate effect should be examined.

Table 2: Mean comparison of some measured characteristics in fenugreek (Greenhouse building at University of Guilan, 2012)

\begin{tabular}{|c|c|c|c|c|c|c|}
\hline \multirow{2}{*}{} & \multicolumn{7}{|c|}{ Means } \\
\cline { 2 - 7 } & $\begin{array}{c}\text { Plant } \\
\text { height } \\
(\mathrm{cm})\end{array}$ & $\begin{array}{c}\text { Number of } \\
\text { pods per plant }\end{array}$ & $\begin{array}{c}\text { Plant fresh } \\
\text { mass } \\
(\mathrm{g})\end{array}$ & $\begin{array}{c}\text { Pod } \\
\text { length } \\
(\mathrm{cm})\end{array}$ & $\begin{array}{c}\text { Pod } \\
\text { fresh } \\
\text { mass } \\
(\mathrm{g})\end{array}$ & $\begin{array}{c}\text { Pod dry } \\
\text { mass } \\
(\mathrm{g})\end{array}$ \\
\hline Treatment & $51 \mathrm{a}$ & $73.33 \mathrm{a}^{\mathrm{a}}$ & $11.67 \mathrm{a}$ & $13.2 \mathrm{a}$ & $8.41 \mathrm{a}$ & $1.02 \mathrm{~b}$ \\
\hline ermicompost & $48 \mathrm{a}$ & $68.67 \mathrm{a}$ & $11 \mathrm{a}$ & $12.81 \mathrm{a}$ & $7.57 \mathrm{a}$ & $1.35 \mathrm{ab}$ \\
\hline Vermiwash & $45.67 \mathrm{a}$ & $74 \mathrm{a}$ & $11.33 \mathrm{a}$ & $12.53 \mathrm{a}$ & $7.74 \mathrm{a}$ & $1.15 \mathrm{ab}$ \\
\hline Vermiwash+vermicompost & $35.67 \mathrm{~b}$ & $64.33 \mathrm{a}$ & $10.33 \mathrm{a}$ & $10.36 \mathrm{~b}$ & $5.78 \mathrm{~b}$ & $1.45 \mathrm{a}$ \\
\hline Control & & & & & \\
\hline
\end{tabular}

a values in columns followed by the same letter are not significantly different, $P<0.05$, Tukey test.

Table 3: Mean comparison of some measured characteristics in fenugreek (Greenhouse building at University of Guilan, 2012)

\begin{tabular}{|c|c|c|c|c|c|c|}
\hline \multirow[b]{2}{*}{ Treatment } & & \multicolumn{5}{|c|}{ Means } \\
\hline & $\begin{array}{c}1000- \\
\text { seed } \\
\text { mass } \\
(\mathrm{g})\end{array}$ & $\begin{array}{c}\text { Number of } \\
\text { nodes }\end{array}$ & $\begin{array}{c}\text { Number of } \\
\text { lateral } \\
\text { branches }\end{array}$ & $\begin{array}{c}\text { Plant fresh } \\
\text { mass } \\
\text { (g) }\end{array}$ & $\begin{array}{c}\text { Plant dry } \\
\text { mass } \\
\text { (g) }\end{array}$ & $\begin{array}{c}\text { Internode } \\
\text { length } \\
\text { (cm) }\end{array}$ \\
\hline Vermicompost & $1.49 \mathrm{a}$ & $9.33 \mathrm{a}^{\mathrm{a}}$ & $9.33 \mathrm{a}^{\mathrm{a}}$ & $49.36 b$ & $23.69 \mathrm{ab}$ & $6.18 \mathrm{a}$ \\
\hline Vermiwash & $1.49 \mathrm{a}$ & $9 \mathrm{a}$ & $9.33 \mathrm{a}$ & $57.12 \mathrm{a}$ & $26.04 \mathrm{a}$ & $5.89 \mathrm{a}$ \\
\hline Vermiwash+vermicompost & $1.28 \mathrm{~b}$ & $8.33 \mathrm{a}$ & $9.33 \mathrm{a}$ & $52.27 \mathrm{ab}$ & $22.57 \mathrm{ab}$ & $6.22 \mathrm{a}$ \\
\hline Control & $0.78 \mathrm{c}$ & $8.33 \mathrm{a}$ & $9.67 \mathrm{a}$ & $43.86 \mathrm{c}$ & $19.44 b$ & $4.24 b$ \\
\hline
\end{tabular}

${ }^{\mathrm{a}}$ values in columns followed by the same letter are not significantly different, $P<0.05$, Tukey test. 
Effects of organic fertilizers on growth and biochemical characteristics of Fenugreek

Table 4: Mean comparison of some measured characteristics in fenugreek (Greenhouse building at university of guilan, 2012)

\begin{tabular}{|c|c|c|c|c|c|c|}
\hline & \multicolumn{6}{|c|}{ Means } \\
\hline Treatment & $\begin{array}{l}\text { Total } \\
\text { yield } \\
(\mathrm{g})\end{array}$ & $\begin{array}{l}\text { Dry } \\
\text { yield } \\
(\mathrm{g})\end{array}$ & $\begin{array}{c}\text { Total } \\
\text { phenol } \\
\text { (mg galic } \\
\text { acid /100 } \\
\text { g) }\end{array}$ & $\begin{array}{c}\text { Antioxidant } \\
\text { capacity } \\
\text { (\% of } \\
\text { inhibition) }\end{array}$ & $\begin{array}{c}\text { Seed } \\
\text { protein } \\
(\%)\end{array}$ & $\begin{array}{c}\text { Nitrogen in } \\
\text { seed } \\
(\%)\end{array}$ \\
\hline Vermicompost & $2453.9 \mathrm{a}^{\mathrm{a}}$ & $298.43 a$ & $4.9 \mathrm{a}^{\mathrm{a}}$ & $39.02 \mathrm{a}$ & $24.35 \mathrm{ab}$ & $4.60 \mathrm{ab}$ \\
\hline Vermiwash & $2076.9 \mathrm{ab}$ & $370.35 a$ & $4.66 \mathrm{a}$ & $38.31 \mathrm{a}$ & $23.83 \mathrm{ab}$ & $4.50 \mathrm{ab}$ \\
\hline Vermiwash+vermicompost & $2280.6 a b$ & $331.76 a$ & $4.58 \mathrm{a}$ & $38.22 \mathrm{a}$ & $24.65 a$ & $4.65 a$ \\
\hline Control & $1490.4 b$ & $372.13 \mathrm{a}$ & $4.34 \mathrm{a}$ & $37.23 \mathrm{a}$ & $20.83 b$ & $3.93 b$ \\
\hline
\end{tabular}

${ }^{\mathrm{a}}$ values in columns followed by the same letter are not significantly different, $P<0.05$, Tukey test.

\section{CONCLUSIONS}

According to the data the addition of the fertilizer provided improvement to some measured variables but a cost:benefit analysis will have to be done to determine if the cost of the fertilizer justifies its use. Further study is needed to confirm these results under field conditions. Use of organic fertilizers beneficially affected plant height, pod length, pod fresh and dry mass, 1000-seed mass, plant fresh and dry mass, internode length and percents of leaves protein and nitrogen. Use of organic fertilizers may increase yield and yield components of fenugreek and its yield efficiency.

\section{REFERENCES}

Adediran JA., Taiwo LB., Akande MO., Sobulo RA., Idowu OJ. (2004). Application of organic and inorganic fertilizer for sustainable maize and cowpea yields in Nigeria. Journal of Plant Nutrition, 27, 1163-1181. doi:10.1081/PLN120038542

Almulla L., Bhat NR., Lekha VS., Thomas B., Ali S., George P., Xavier M. (2012). Effect of three organic fertilizer formulations on growth and yield of cherry tomato (Lycopersicon esculentum cv. Sakura) under soilless organic greenhouse production system. European Journal of Scientific Research, 80(3), 281-288.

Arguello JA., Ledesma A., Nunez SB., Rodriguez CH., Goldfarb MDD. (2006). Vermicompost effects on bulbing dynamics, nonstructural carbohydrate content, yield and quality of Rosado paraguayo garlic bulbs. Horticultural Sciences, 41(3), 589592.

Arancon N., Edwards CA., Bierman PC., Metzger JD. (2004a). Influences of vermicomposts on field strawberries: 1. Effects on growth and yields. Bioresource Technology, 93, 145-153. doi:10.1016/j.biortech.2003.10.014

Arancon NQ., Edwards CA., Atieyh RM., Metzger JD. (2004b). Effect of vermicomposts produced from food waste on the growth and yields of greenhouse peppers. Bioresource Technology, 93, 139-143. doi:10.1016/j.biortech.2003.10.015

Arancon NQ., Galvis PA., Edwards A. (2005). Suppression of insect pest populations and damage to plants by vermicomposts. Bioresource Technology, $\quad 96(10), \quad 1137-1142$. doi:10.1016/j.biortech.2004.10.004 
Asami D., Hang Y., Barnett D., Mitchelle A. (2003). Comparison of the total phenolic and ascorbic content of freeze-dried and air dried marionberry, strawberry, and corn grown using conventional, organic and sustainable agricultural practices. Journal of Agricultural and Food Chemistry, 51, 1237-1241. doi:10.1021/jf020635c

Atiyeh RM., Arancon N., Edwards CA., Metzger JD. (2002). The influence of earthworm processed pigmanure on the growth and productivity of marigolds. Bioresource Technology, 81, 103-108. doi:10.1016/S0960-8524(01)00122-5

Bradford M. (1976). A rapid and sensitive method for the quantitation of microgram quantities of protein utilizing the principle of protein-dye binding. Analytical Biochemistry, 72, 248-254. doi:10.1016/0003-2697(76)90527-3

Bukhari SB., Bhanger MI., Memon S. (2008). Antioxidative activity of extracts from Fenugreek seeds (Trigonella foenum-graecum). Pakistan Journal of Analytical \& Environmental Chemistry, 9(2), 78-83.

Dixon RA. (2001). Natural products and plant disease resistance. $\quad$ Nature, 411, 843-847. doi: $10.1038 / 35081178$

Du G., Li M., Ma F., Liang D. (2009). Antioxidant capacity and the relationship with polyphenol and vitamin $\mathrm{C}$ in Actinidia fruits. Journal of Agricultural and Food Chemistry, 113, 557-562. doi:10.1016/j.foodchem.2008.08.025

Gunadi B., Edwards CA., Blount C. (2002). The influence of different moisture levels on the growth, fecundity and survival of Eisenia foetida (Savigny) in cattle and pig manure solids. Soil Biology and Biochemistry, 39, 19-24.

Haghighi M. (2001). Sewage sludge application in soil improved leafy vegetable growth. Journal of Biological \& Environmental Sciences, 5(15), 165167.

Haouala R., Hawala S., El-Ayeb A., Khanfir R., Boughanmi N. (2008). Aqueous and organic extracts of Trigonella foenum-graecum L. inhibit the mycelia growth of fungi. Journal of Environmental Sciences, 20, 1453-1457. doi:10.1016/S1001-0742(08)62548-6

Kasthuri H., Shanthi K., Sivakumar S., Rajakumar SH., Son K., Song YC. (2011). Influence of municipal solid waste compost (MSWC) on the growth and yield of green gram [Vigna radiate (L.) Wilczek], fenugreek (Trigonella foenum-graecum L.) and on soil quality. Iranian Journal of Environmental Health Science \& Engineering, 8(3), 285-294.
Kaviarasan S., Naik GH., Gangabhagirathi R., Anuradha CV., Priyadarsini KI. (2007). In vitro studies on antiradical and antioxidant activities of fenugreek (Trigonella foenumgraecum) seeds. Journal of Agricultural and Food Chemistry, 103, 31-37. doi:10.1016/j.foodchem.2006.05.064

Muscolo A., Bovalo F., Gionfriddo F., Nardi S. (1999). Earthworm humic matter produces auxin-like effects on Daucus carota cell growth and nitrate metabolism. Soil Biology and Biochemistry, 31, 1303-1311. doi:10.1016/S0038-0717(99)00049-8

Pant AP., Radovich TJK., Hue NV., Talcottb ST., Krenekb KA. (2009). Vermicompost extracts influence growth, mineral nutrients, phytonutrients and antioxidant activity in pakchoi (Brassica rapa cv. Bonsai, Chinensis group) grown under vermicompost and chemical fertilizer. Journal of the Science of Food and Agriculture, 89, 23832392. doi:10.1002/jsfa.3732

Peyvast Gh., Olfati JA., Madeni S., Forghani A. (2008). Effect of vermicompost on the growth and yield of spinach (Spinacia oleracea L.). Journal of Food Agriculture and Environment, 16(1), 110-113.

Rani TS., Nishana H. (2012). Influence of different sources of organic manure, vermiwash and AMF on growth and yield of bhindi (Abelmoschus esculentus L. Moench). Plant Archives, 12(1), 7578.

Renato Y., Ferreira ME., Cruz MC., Barbosa JC. (2003). Organic matter fractions and soil fertility underinfluence of liming, vermicopmpost and cattle manure. Bioresource Technology, 60, 59-63.

Singleton VL., Orthofer R., LamuelaRaventós RM. (1999). Analysis of total phenols and other oxidation substrates and antioxidants by means of Folin-Ciocalteu reagent. Methods of Enzymology, 299, 152-178. doi:10.1016/S0076-6879(99)990171

Suthar S. (2008). Bioconversion of postharvest crop residues and cattle shed manure into value-added products using earthworms Eudrilus eugeniae Kinberg. Ecological Engineering, 32, 206-214. doi:10.1016/j.ecoleng.2007.11.002

Suthar S. (2010). Pilot-scale vermireactors for sewage sludge stabilization and metal remediation process: Comparison with small-scale vermireactors. Ecological Engineering, 2009.12.016. doi:10.1016/j.ecoleng.2009.12.016

Taylor M., Clarke WP., Greenfield PF. (2003). The treatment of domestic wastewater using small-scale vermicompost filter beds. Ecological Engineering. 
21(2-3),

doi:10.1016/j.ecoleng.2003.12.003

Wang SY., Lin S. (2002). Compost as soil supplement enhanced plant growth and fruit quality of strawberry. Journal of Plant Nutrition, 25, 11432259. doi:10.1081/pln-120014073
197-203. Yadav RL., Keshwa GL., Yadav SS. (2003). Effect of integrated use of FYM and sulphure on growth and yield of isabgol. Journal of Medicinal and Aromatic Plant Sciences, 25, 668-671. 